\title{
Tawazaun
}

Jurnal Pendidikan Islam

http://ejournal.uika-bogor.ac.id/index.php/TAWAZUN/index

Vol. 14, No. 1, 2021, e-ISSN: 2654-5845, hlm. 1-14, DOI: 10.32832/tawazun.v14i1.4010

\section{Nilai-nilai Keimanan dalam Pemikiran Sejarah Ibnu Khaldun pada Kitab al-Muqaddimah}

\author{
Saepul Japar Sidik ${ }^{1}$, Abas Mansur Tamam¹, Hasbi Indra ${ }^{1}$ \\ ${ }^{1}$ Sekolah Pascasarjana Universitas Ibn Khaldun Bogor \\ saefuljafarshidieq@gmail.com
}

\begin{abstract}
Ibn Khaldun's Kitab al-Muqaddimah is known as a monumental historical work. From his introductory work on his book al-'Ibarnya, Ibn Khaldun is known as the Father of Historiography and the Historian of Philosophy. His theories about history are often known as empiricalrationalist works. However, works that are considered empirical-rationalist do not pay attention to the values of faith in them. Even other researchers say that Ibn Khaldun's historical thoughts were reconstructed from the values of revelation (al-Qur'an and al-Hadith). The research method used is the library method or also known as libraly research. The temporary conclusion from this research is that there are values of faith in the historical thought of Ibn Khaldun in his alMuqaddimah book.
\end{abstract}

Keywords: Faith values, Ibn Khaldun's historical thought, al-Muqaddimah

Abstrak

Kitab al-Muqaddimah karya Ibnu Khaldun dikenal sebagai karya sejarah yang monumental. Dari karya pengantar atas kitab al-'Ibarnya inilah Ibnu Khaldun dikenal sebagai Bapak Historiografi dan Sejarawan Filosof. Teori-teorinya tentang sejarah, acapkali dikenal sebagai karya yang empirisrasionalis. Namun demikian, karya yang dinilai empiris-rasionalis tidak mengindahkan nilai-nilai keimanan di dalamnya. Bahkan peneliti lain menyebutkan bahwa pemikiran sejarah Ibnu Khaldun direkonstruksi dari nilai-nilai wahyu (al-Qur'an dan al-Hadits). Metode penelitian yang digunakan adalah metode pustaka atau disebut juga dengan libraly research. Konklusi sementara dari penelitian ini adalah terdapat nilai-nilai keimanan dalam pemikiran sejarah Ibnu Khaldun pada kitab al-Muqaddimahnya.

Kata Kunci: Nilai-nilai Keimanan, Pemikiran Sejarah Ibnu Khaldun, al-Muqaddimah.

\section{Pendahuluan}

Abdurrahman atau lebih dikenal dengan nama Ibnu Khaldun, adalah satu-satunya cendekiawan Muslim yang tetap kreatif menghidupkan khazanah intelektualisme Islam pada periode abad Pertengahan, di saat para cendekiawan Muslim lainnya hanya mampu melakukan evaluasi, kanonisasi dan atau memberikan ulasan serta kritik terhadap karya-karya abad Keemasan Islam saja. Sehingga hasilnya adalah ilmu pengetahuan Islam mengalami kemunduran dan kemandekan (Toto, 2010).

Maka pantas jika banyak pujian yang disematkan kepada Ibnu Khaldun. Robert Flint, seorang pakar sejarah filsafat berkebangsaan Inggris mengatakan bahwa literatur Arab dihiasi oleh satu nama yang sangat cemerlang, yakni Ibnu Khaldun. Tidak ada yang dapat menandinginya, bahkan Plato, Aristoteles, dan Augustine tidak dapat menandinginya; George Sarton, pakar sejarah ilmu pengetahuan berkebangsaan Amerika menganggap Ibnu Khaldun sebagai pakar sejarah, politik, sosiologi, dan pakar ekonomi; Cyril Glasse telah memandang Ibnu Khaldun sebagai Bapak Historiografi; Syafi'i Ma'arif lebih suka menyebut Ibnu Khaldun sebagai sejarawan filosof (Toto, 2010).

Article Information: Received January 05, 2021, Accepted April 08, 2021, Published April 22, 2021

Published by: Program Studi Magister Pendidikan Agama Islam Universitas Ibn Khaldun Bogor

How to cite: Sidik, S. J., Tamam, A. M., \& Indra, H. (2021). Nilai-nilai Keimanan dalam Pemikiran Sejarah Ibnu

Khaldun pada Kitab al-Muqaddimah. Tawazun: Jurnal Pendidikan Islam, 14(1).

https://doi.org/10.32832/tawazun.v14i1.4010 
Ada sekitar 269 kajian tentang pemikiran Ibnu Khaldun yang diterbitkan dalam bentuk buku, majalah, maupun disertasi, baik dalam berbahasa Arab maupun dalam berbahasa asing. Judul kajian tersebut secara komplit tercantum dalam karya Abdurrahman al-Badawi (1962) dalam kitab al-Mu'allafät Ibnu Kabldun.

Ini sebagai bukti bahwa pemikiran Ibnu Khaldun yang tertuang dalam magnum opusnya, Muqaddimah Ibnu Khaldun, mampu mengejutkan barat dan Timur. Namun sangat disayangkan sekali, bahwa kajian dan perhatian tentang pemikiran Ibnu Khaldun banyak datang dari barat. Bahkan baratlah yang pertama kali mengkaji dan mempublikasikannya sehingga pemikiran Ibnu Khaldun dapat mendunia.

Adalah Barthelmy d'Herbelot de Molainville yang pertama kali mempublikasikan makalahnya tentang Ibnu Khaldun dalam Bibliotheque Orientale pada tahun 1679 M. Menurut al-Khudhairi dalam makalahnya terdapat banyak kekeliruan sehingga tidak dapat mengungkapkan esensi dan nilai yang terkandung dalam Muqaddimab Ibnu Khaldun. Namun demikian, sebagai pelopor dan yang mengawali kajian tentang pemikiran besar Ibnu Khaldun yang hampir terlupakan, patut dihargai dan diapresiasi (Al-Khudhairi, 1995). Setelah itu, bermunculan tentang kajian Ibnu Khaldun secara berangsur-angsur dari tahun $1816 \mathrm{M}$ sampai $1886 \mathrm{M}$ hingga sekarang ini.

Pemikirannya tentang sejarah memberikan sumbangsih besar terhadap paradigma baru tentang kajian sejarah. Menurut Ibnu Khaldun, sejarah merupakan sebuah disiplin ilmu yang mendapatkan banyak perhatian dari berbagai kalangan; mulai dari penguasa sampai rakyat biasa; dari cendekiawan sampai orang tak terpelajar, semuanya menikmati ilmu sejarah (Ibnu Khaldun, 2004).

Oleh karena mendapatkan banyak perhatian dari berbagai kalangan, maka memerlukan pendekatan yang benar dalam mengkajinya. Di samping memerlukan berbagai rujukan otoritatif, ketelitian, dan multidisiplin ilmu pengetahuan, ilmu sejarah juga mesti dikaitkan dengan prinsip-prinsip adat, kaidah-kaidah politik, tabiat peradaban, kondisi-kondisi sosial masyarakat, serta yang gaib, dan mampu mengkontekstualisasikan masa lalu dengan masa kini. Jika itu tidak dilakukan, kata Ibnu Khaldun, akan berpotensi besar pada kekeliruan dan penyimpangan sejarah. Berikut penuturan Ibnu Khaldun (2004):

Ilmu sejarah membutuhkan banyak rujukan, beragam ilmu pengetahuan, dan nalar yang cermat serta ketelitian yang dengan keduanya dapat menghantarkan kepada kebenaran dan menyelamatkan dari berbagai ketergelinciran dan kekeliruan. Karena jika sejarah hanya sebatas menukil, tanpa pertimbangan prinsip-prinsip adat, kaidah-kaidah politik, karakteristik peradaban, kondisi sosio-kultural masyarakat, tidak dianalogikan pada yang gaib, masa kini tidak dianalogikan dengan masa lalu, maka sejarah seperti itu tidak akan aman dari ketersandungan, ketergelinciran, dan kecongkakan dari jalan kebenaran.

Kemudian Ibnu Khaldun mengkritik sejarawan seperti al-Mas'udi, ath-Thabari, dan alJurjani. Kritikannya terhadap mereka didasari metodologi yang mereka gunakan tidak tepat dalam pandangan Ibnu Khaldun. Karena mereka hanya sekedar menukil sebuah riwayat tanpa memilah mana yang benar dan mana yang batil, lalu tidak menganalogikannya dengan peristiwa yang serupa, tidak menimbangnya dengan timbangan hikmah dan nalar kritis.

Sebagai contoh, Ibnu Jarir menafsirkan kata Iräm pada QS. Al-Fajr [89]: 6-7 sebagai sebuah negeri atau kota yang didiami oleh kaum 'Ad. Berikut teks ayat dan komentar Ibnu Jarir terhadap ayat tersebut:

$$
\text { أَلْمْ تَزَ كَيْفَ فَعَلَ رَبُّكَ بِعَادٍ (6) إِرَمَ ذَاتِ الْعِمَادِ (7) }
$$

Apakah kamu tidak memperhatikan bagaimana Tuhanmu berbuat terhadap kaum 'Aad?. (yaitu) Penduduk Iram yang mempunyai bangunan-bangunan yang tinggi. 
Dalam tafsirnya, Ibnu Jarir (2001) mengutip beberapa riwayat mengenai penafsiran Iräm. Di antaranya ada yang menafsirkan bahwa Iräm adalah kota Iskandariah; ada juga yang menafsirkan kota Damaskus; ada yang menafsirkan sebagai generasi pertama kaum 'Ad; dan ada juga yang menafsirkan nama kabilah kaum 'Ad. Dari semua penafsiran itu semua, Ibnu Jarir cenderung dan memilih bahwa makna Iräm pada ayat di atas adalah nama kota yang ditinggali oleh kaum 'Ad tanpa menyebut nama kotanya.

Cerita tentang kota Iräm dikritisi oleh Ibnu Khaldun. Menurutnya, kota seperti itu tidak pernah disebutkan sama sekali oleh para generasi setelahnya, bahkan oleh para ahli sejarah sekalipun. Seandainya jika dikatakan bahwa kota Iräm telah lenyap beserta bekas-bekas peradabannya, maka menurut Ibnu Khaldun hal itu dapat diterima nalar. Namun sayangnya, malah muncul ke permukaan bahwa kota Iräm itu sebenarnya ada namun tidak bisa terlihat oleh kasat mata atau mata biasa; yang dapat melihatnya adalah mereka yang spiritualnya terlatih atau yang pandai sihir. Semua pendapat ini, jelas menurut Ibnu Khaldun sebagai cerita khurafat.

Cerita di atas merupakan salah satu contoh yang mendapat kritikan dari Ibnu Khaldun. Bagi Ibnu Khaldun, kisah atau dongeng serupa tidak pantas untuk dinisbahkan kepada kitab suci al-Qur'an, terlebih ilmu sejarah merupakan ilmu yang mulia yang kemudian setiap jejak peristiwanya dapat diambil ibrah dan pelajaran yang berharga untuk dunia dan agama. Kebermanfaatan ilmu sejarah baik dalam aspek duniawi dan ukhrawi ditegaskan oleh Ibnu Khaldun dalam kitab Muqaddimanya sebagai berikut:

Ketahuilah bahwa ilmu sejarah adalah ilmu yang mulia mazhabnya, besar manfaatnya, mulia tujuannya. Ilmu sejarah membuat kita tahu tentang kondisi umat-umat terdahulu, jejakjejak para nabi, kekuasaan dan politik para raja, sehingga dapat dijadikan pelajaran bagi orangorang yang mengambil pelajaran, baik dalam urusan agama atau dunia.

Bila kita perhatikan kitab Muqaddimah, sebagai kitab sejarah yang menggunakan pendekatan empiris-rasionalis, tidak menghilangkan sama sekali aspek-aspek keimanan di dalamnya. Hal itu bisa dilihat dari setiap akhir pembahasannya baik dalam bab atau sub babnya, selalu menganggungkan nama Allah azza wa jalla dan mengutip ayat-ayat al-Qur'an. Sebagai contoh, tertulis "Hanya kepada Allab Swt. kita meminta untuk menjadikan amal-amal kita murni karena wajah-Nya, bersih dari kotoran-kotoran lalai dan syubhat. Dialab Pencukup kita dan Dia sebaik-baik penolong" di akhir kata pengantarnya; tertulis "Hanya Allah yang memberikan taufik dan pertolongan untuk mencapai kebenaran" di akhir pembahasan pasal pertama; tertulis ayat alQur'an yang berbunyi "Dan di dalam penciptaan langit dan bumi dan perbedaan malam dan siang terdapat tanda-tanda bagi orang yang berpengetabuan (QS. Ali Imran: 190)" yang tercantum di akhir pembahasan tentang iklim dari suatu kawasan.

Ibnu Khaldun dalam kitab sejarahnya tidak membahas tentang iman, karena itu bukan wilayah ilmu sejarah, namun secara implisit menjadikannya kompetensi dalam aspek spiritual sebagai tujuan dari mempelajari ilmu sejarah. Pemikiran sejarah Ibnu Khaldun sangat relevan dengan kurikulum 2013 yang menjadikan kompetensi spiritual sebagai salah satu standar kompetensi lulusan pada seluruh mata pelajaran, termasuk mata pelajaran Sejarah Indonesia.

Penelitian-penelitian terdahulu tentang tema ini di antaranya: Pertama, penelitian Samsinas yang berjudul Ibnu Khaldun: Kajian Tokoh Sejarah dan Ilmu-ilmu Sosial. Penelitian ini ditujukan untuk mengkaji pemikiran Ibnu Khaldun dari sudut pandang para ilmuan (Samsinas, 2009). Kedua, penelitian Syamsul Hidayat dan Ana Nur Wakhidah yang berjudul Konsep Pendidikan Islam Ibnu Khaldun dan Relevansinya Terhadap Pendidikan Nasional. Penelitian ini mencoba mengungkap konsep pendidikan Islam menurut Ibnu Khaldun dan relevansinya dengan pendidikan nasional (Syamsul dan Ana Nur, 2015). Ketiga, penelitian Budi Sujati yang berjudul Konsepsi Pemikiran Filsafat Sejarah dan Sejarah Menurut Ibnu Khaldun. Penelitian ini membahas tentang sejarah dengan menggunakan pendekatan filsafat dari sudut pandang 
filsafat sejarah Ibnu Khaldun (Budi, 2018). Keempat, Visi Pendidikan Islam: Perspektif Ibn Khaldun, dalam penelitian yang ditulis Didin Saepudin dan Saifudin. Artikel tersebut menyimpulkan mengenai visi pendidikan Islam dalam pandangan Ibn Khaldun yaitu membentuk pribadi Muslim yang berbakat secara intelektual, kepribadian (moral/akhlak). Selain itu tujuan Pendidikan juga harus bersifat pragmatis, yaitu memberikan skill yang relevan dengan tuntutan zamannya (Saepudin \& Saifudin, 2019).

Dari penelitian-penelitian terdahulu, maka penelitian ini bisa dikatakan penelitian baru yang membahas secara fokus antara pemikiran sejarah Ibnu Khaldun dengan nilai-nilai keimanan yang ada pada kitab al-Muqaddimah.

Penelitian ini diharapkan memberikan paradigma baru mengenai metodologi penulisan sejarah yang hari ini cenderung sekularistik-materialistik. Ibnu Khaldun telah membuktikan bahwa Sejarah dan nilai-nilai spiritual bisa padu dan harmoni dengan tetap berada di wilayahnya masing-masing.

\section{Metode Penelitian}

Metode yang digunakan dalam penelitian ini adalah metode deskriptif-analitik, yaitu dengan cara mendeskripsikan fakta-fakta yang ada untuk kemudian dianalisis. Metode deskriptif analitik merupakan suatu metode penelitian dengan cara mendeskripsikan faktafakta yang kemudian disusul dengan analisis (Ratna, 2013: 53). Langkah-langkah yang dilakukan dalam penelitian ini ialah mengadakan studi kepustakaan, mengumpulkan data, mengolah data, menganalisis data, dan menarik kesimpulan (Soeratno, 1994: 22).

Menurut ciri dan karakteristiknya, penelitian ini masuk dalam kategori penelitian yang menggunakan metode deskriptif kualitatif dengan pendekatan kajian pustaka (library research).

Menurut Wina Sanjaya bahwa penelitian kualitatif berangkat dari filsafat fenomenologis. Menurut aliran filsafat ini bahwa sesuatu yang tampak akan bermakna jika ada subjek yang memaknainya. Dengan kata lain suatu fakta yang terjadi tidak bisa memaknai dirinya sendiri, tanpa melalui peran subjek (Wina, 2013).

Karakteristik penelitian kualitatif terletak pada objek yang menjadi fokus penelitian dan lebih menekankan kepada kualitas secara alamiah yang menyangkut pengertian, konsep, nilai serta ciri-ciri yang melekat pada objek penelitian lainnya. Menurut Kaelan, penelitian kualitatif sangat relevan dalam studi humaniora, baik studi teks maupun studi humaniora lainnya (Kalelan, 2010).

Penelitian deskriptif (descriptive research) merupakan penelitian yang dilaksanakan dengan tujuan penting untuk menggambarkan atau mendeskripsikan tentang suatu kondisi secara objektif (Asep, 2018).

Dari uraian di atas dapat disimpulkan bahwa penelitian deskriptif kualitatif adalah metode penelitian yang bertujuan untuk menggambarkan secara utuh dan mendalam tentang realitas sosial dan berbagai fenomena yang terjadi di masyarakat yang menjadi subjek penelitian sehingga tergambarkan ciri, karakter, sifat, dan model fenomena tersebut.

Penelitian teks atau penelitian pustaka dalam hubungannya dengan ilmu humaniora, dapat dibedakan menjadi dua macam: (1) penelitian pustaka yang memerlukan olahan uji kebermaknaan empiri di lapangan, dan (2) penelitian secara filosofis dan teoritis. Untuk metode penelitian yang pertama memiliki kegunaan untuk membangun konsep teoritis dengan melalui suatu uji kebermaknaan di lapangan secara empiris. Untuk metode kualitatif jenis kedua yaitu penerapan metode kualitatif pada bidang-bidang humaniora yang hampir seluruh substansinya memerlukan olahan kebermaknaan secara filosofis. 
Adapun sumber yang digunakan dalam penelitian ini terbagi kepada dua bagian; primer dan sekunder. Sumber primer yang dimaksud adalah Muqaddimah Ibn Khaldun dan seluruh karya-karyanya. Sedangkan sumber sekunder yang dimaksud adalah buku, artikel, jurnal, dan lain sebagainya yang membahas tentang pemikiran Ibnu Khaldun.

\section{Hasil dan Pembahasan}

Muqaddimah Ibnu Khaldun adalah satu di antara karya-karyanya yang di Eropa dikenal dengan kitab filsafat sejarah pada abad ke-18 dan dikenal dengan ilmu sejarah atau pengantar ilmu sejarah pada abad ke-19 (Sathi, 1967). Dalam pemikiran Ibnu Khaldun, sejarah tidak hanya sebatas membahas tentang tema-tema seputar penaklukan, peperangan, negara, penguasa, dan yang semisal dengannya. Lebih dari itu, sejarah membahas tentang perubahanperubahan kehidupan suatu masyarakat yang di dalamnya mencakup hal-hal yang berkaitan dengan perekonomian, perindustrian, dan ilmu pengetahuan (Husain, 1991). Tegasnya, ilmu sejarah membutuhkan ilmu bantu sebagai pisau analisanya. Berkenaan hal ini Ibnu Khaldun berkata sebagai berikut:

"Penulisan sejarah memerlukan sumber yang beragam dan pengetahuan yang bermacammacam... Apabila catatan sejarah hanya didasarkan kepada bentuk penukilan, dan tidak didasarkan kepada pengetahuan yang jelas tentang prinsip-prinsip yang ditarik dari kebiasaan, tentang fakta-fakta politik yang fundamental, tentang watak peradaban, tentang segala hal ihwal yang terjadi dalam kehidupan sosial manusia...pasti akan ditemukan batu penghalang, ketergelinciran dan kekhilafan di dalam berita sejarah tersebut."

Setidaknya, menurut Renier, ada dua klasifikasi ilmu bantu dalam ilmu sejarah, yaitu ancillary disciplines dan auxilary sciences. Pengetahuan pada kelompok pertama di antaranya adalah Kronologi (pengetahuan tentang terjadinya peristiwa berdasarkan urutan waktu kejadian), Diplomatik (pengetahuan tentang tanggal, tempat dan palsu atau tidaknya suatu dokumen), Paleografi (pengetahuan tentang tulisan-tulisan kuno), Epigrafi (pengetahuan tentang tulisan-tulisan yang terdapat pada monumen-monumen), Sigilografi (pengetahuan tentang segel-segel), Heraldry (pengetahuan tentang simbol-simbol yang terdapat pada senjata sehingga diketahui siapa pemakainya), Numismatik (pengetahuan tentang mata uang menurut negara dan zamannya), dan Genealogi (pengetahuan tentang asal-usul keturunan atau silsilah). Sedangkan ilmu-ilmu pada kelompok kedua di antaranya adalah Sosiologi, Ilmu Ekonomi, Ilmu politik, Antropologi, Arkeologi, Geografi, dan sebagainya (Renier, 1997).

Ilmu bantu yang dikehendaki Ibnu Khaldun menurut Mahdi -sebagaimana yang dikutip Toto- adalah 'ilmu al-'umrān. Namun apa yang dimaksud dengan ilmu al-umrän? Menurut Toto ada empat kelompok Khaldunian yang mencoba menginterpretasi maksud dari ilmu al-umrān tersebut. Kelompok pertama diwakili oleh Baali, Enan, Hitti, dan Issawi. Mereka umumnya menyatakan bahwa yang dimaksud Ibnu Khaldun dengan ilmu al-umrān adalah sosiologi atau ilmu tentang masyarakat. Kelompok kedua berpendapat bahwa yang dimaksud dengan ilmu al-'umrān adalah ilmu kultur. Pendapat ini dikemukakan oleh Mahdi. Adapun kelompok ketiga diwakili oleh al-Khudhairi yang beranggapan bahwa yang dimaksud Ibnu Khaldun dengan ilmu al-umrān adalah filsafat sejarah. Sedangkan kelompok terakhir menyatakan bahwa yang dimaksud dengan ilmu al-'umrān oleh Ibnu Khaldun adalah ilmu sosial dan budaya. Kelompok terakhir ini didukung oleh Syafi'i Ma'arif.

Pendapat Syafi'i Ma'arif ini didukung oleh Toto dengan merujuk kepada pendapat pendukungnya, yaitu al-Jabiri yang menjelaskan tentang thaba'i al-' umrān. Menurutnya, yang dimaksud thaba'i al-' umrān oleh Ibnu Khaldun adalah dinamika-dinamika atau fenomenafenomena yang biasa terjadi dalam dirinya. Dengan kata lain, thaba'i al-' umrän adalah konsep universalitas yang berlaku dalam kehidupan sosial atau al-kulliyyah al-ijtima'tiyyah. Jadi, thaba'i 
al-" umrän adalah fenomena-fenomena yang biasa terjadi dalam kehidupan sosial manusia, bersifat pasti dan tunduk kepada hukum kausalitas (sebab-akibat).

Oleh karena itu, sangat wajar jika Ibnu Khaldun dikenal sebagai perintis dari sosiologi. Hal itu dikarenakan ide-ide yang dikemukakannya sangat menarik dalam bidang sosiologi sehingga pantas Ibnu Khaldun disebut sebagai perintis sosiologi. Demikian menurut alKhudhari.

\section{A. Ibnu Khaldun dan Pemikiran Sejarahnya}

Persinggungan Ibnu Khaldun dengan ilmu sejarah merupakan perjalanan yang sangat panjang dan tidak disangka-sangka. Keputusannya untuk mengarang karya sejarah disebabkan dua faktor. Faktor pertama karena pengalaman politiknya. Faktor kedua karena kontemplasi intelektualnya. Yang menurut Abu Inan, faktor pertama merupakan faktor yang sangat besar pengaruhnya terhadap faktor kedua yang menghasilkan karya sejarahnya (AlKhudhairi, 1995). Maka dari itu, akan kita temukan teori-teori sejarahnya merupakan kompilasi dari pengalaman politiknya dan kontemplasi intelektualnya.

Ibnu Khaldun bukanlah orang yang pertama dalam menulis ilmu sejarah. Banyak para cendekiawan muslim yang mendahuluinya dalam penulisan sejarah. Ibnu Ishaq (w. 767/ 768 M) penulis Sirah Mubammad, Muhammad Ibnu Jarir ath-Thabari (839-923 M) penulis Tärikeh ar-Rasül wa al-Mulük, Muhammad bin Umar al-Waqidi (747-823 M) penulis al-Maghäzi, Ali bin Husain al-Mas'udi (w. 956/957 M) penulis Muruj ad₹-Dzabab wa al-Ma'adin wa al-Jaubar, dan sejarawan yang lainnya adalah cendekiawan muslim yang lebih dulu karya sejarahnya ada sebelum karya sejarahnya Ibnu Khaldun.

Namun demikian, Ibnu Khaldun mengkritik karya-karya tersebut yang dianggap hanya mengandalkan metode penukilan semata, tanpa memberikan interpretasi terhadap isi berita yang dinukilnya.

Ilmu sejarah membutuhkan banyak rujukan, beragam ilmu pengetahuan, dan nalar yang cermat serta ketelitian yang dengan keduanya dapat menghantarkan kepada kebenaran dan menyelamatkan dari berbagai ketergelinciran dan kekeliruan. Karena jika sejarah hanya sebatas menukil, tanpa pertimbangan prinsip-prinsip adat, kaidah-kaidah politik, karakteristik peradaban, kondisi sosio-kultural masyarakat, tidak dianalogikan pada yang gaib, masa kini tidak dianalogikan dengan masa lalu, maka sejarah seperti itu tidak akan aman dari ketersandungan, ketergelinciran, dan kecongkakan dari jalan kebenaran.

Al-Mas'udi adalah satu di antara sejarawan yang mendapatkan kritikan dari Ibnu Khaldun. Al-Mas'udi misalnya menukil tentang cerita pasukan Bani Isra'il yang berjumlah 6.000 lebih pasukan saat dikumpulkan oleh Musa di kota Tih dalam suatu pertempuran. AlMas'udi tampaknya lupa bahwa Mesir dan Syiria tidak cukup luas untuk menampung tentara sebanyak itu. Bila pun itu terjadi, maka pertempuran akan berlangsung secara berdesakdesakan dan sulit untuk memobilasi pergerakan militer di antara kedua belah pihak, karena tidak ada ruang untuk bergerak, dan hal ini dalam pandangan Ibnu Khaldun sangat mustahil.

Cuplikan di atas hanyalah satu di antara kritikan yang diutarakan Ibnu Khaldun dalam kitabnya al-Muqaddimah. Secara lengkap, Ibnu Khaldun menyebutkan poin-poin dari kelemahan para sejarawan yang dianggapnya menjadi penyebab karyanya jauh dari kebenaran dan objektivitas.

Pertama, tasyayyuāt li al-arā wa al-madzāhib. Yaitu sikap memihak terhadap salah satu pendapat dan mazhab. Karena bila pikiran dalam kondisi netral pada setiap keterangan, maka pikiran tersebut akan menyelidiki dan meneliti sampai ia mampu menyerpih kebenaran dari ketidakbenaran; memisahkan keaslian dari kepalsuan; dan mengeluarkan fakta dari 
asumsi belaka. Namun, jika pikiran sudah memiliki tendensi terhadap satu pendapat atau mazhab, maka ia akan mudah terjatuh pada ketidakbenaran, kepalsuan, dan kesalahan.

Kedua, ats-tsiqatu bi an-nāqilīn. Yaitu terlalu berpegang teguh kepada para penukil tanpa melalui proses ta'dil wa tajrìh. Metode ta'dil dan tajrïh merupakan salah satu pembahasan dalam ilmu hadits yang diperuntukkan untuk mengungkap sisi kepribadian dari para penutur (penukil) atau personality criticism. Jarb menurut ahli hadits ialah cacat atau tercelanya kepribadian perawi hadits dari sisi akhlak ('adalab) dan dari sisi kredibilitasnya (kekuatan hafalan). Sedangkan $t a^{\prime} d i l$ sebalik darinya, yaitu kepribadian perawi hadits yang tidak memiliki cacat dari aspek akhlak dan dari aspek kredibilitasnya. Namun, ta'dïl dan tajrïh ini dilakukan setelah dapat dipastikan bahwa berita itu masuk dalam kategori wilayah imkān, sesuatu yang tidak mustahil terjadi. Jika berita tersebut masuk dalam kategori wilayah istihälah, sesuatu yang mustahil terjadi, maka secara otomatis berita tersebut ditolak dengan tanpa melakukan ta'dil dan tajrih.

Ketiga, adz-dzuhūl 'an al-maqāshid. Kebingungan dalam menangkap maksud sejarah. Hal ini terjadi kepada para penukil yang gagal menangkap maksud dari apa yang ia lihat dan yang ia dengar; ia menukilnya hanya sebatas pada praduga semata sehingga jatuh pada kekeliruan. Sebab ketiga ini menurut Sathi al-Husri, meliputi pengamatan psikologis yang benar. Dengan kata lain, si pencatat sejarah benar dalam mencatat suatu berita, namun ia keliru dalam memahaminya.

Keempat, tawahhum as-shidq. Yaitu keyakinan yang salah terhadap kebenaran. Pada umumnya hal ini sering terjadi dalam bentuk terlalu memutlakkan kebenaran terhadap apa yang disodorkan para penukil. Sebab yang kedua ini, menurut al-Khudhairi, bisa dimasukkan pada poin kedua karena ada kesamaan dan kemiripan.

Kelima, al-jahlu bi tathbīq al-ahwāl 'ala al-waqā'iq. Yaitu tidak mampu secara tepat menempatkan suatu peristiwa pada proporsi yang sebenarnya, karena kabur dan rumitnya keadaan. Si narator merasa puas dengan menguraikan peristiwa seperti yang dilihatnya, akibatnya terjadilah pemutarbalikan fakta sejarah.

Keenam, taqarrabun nās. Yaitu dapat mengambil hati para penguasa dan pembesar merupakan tujuan dalam penulisan sejarah, sehingga sejarah ditulis untuk kepentingan oportunis dan pragmatis para penguasa dan pembesar. Menurut al-Khudhairi, apabila sejarawan berupaya mendekatkan diri kepada para pemegang kekuasaan dan jabatan tinggi, demi memperoleh kenikmatan duniawi, maka akan mendorongnya menyebarkan beritaberita bohong tentang para penguasa dan pembesar demi menyenangkan pihak penguasa atau pembesar yang didekatinya.

Ketujuh, al-jahlu bi thabāi'i al-ahwāl fi al-'umrān. Yaitu tidak mengetahui watak perubahan sosio-kultural. Padahal -menurut Ibnu Khaldun-, baik benda maupun perbuatan, keduanya tunduk pada watak perubahasan sosio-kultural. Jika si pendengar memahami watak peristiwa, kondisi dan perubahan yang terjadi, maka pengetahuan seperti ini akan membantunya melebihi apa pun dalam menguraikan setiap peristiwa yang dicatatnya dan untuk memilah kebenaran dari kebohongan yang terkandung dalam catatan sejarah tersebut.

Ketujuh kritikan tersebut, mengharuskan Ibnu Khaldun untuk menawarkan langkahlangkah metodologis dalam pengkajian sejarah yang berbeda dengan pengkajian sejarah sebelumnya. Langkah-langkah tersebut secara ringkas diklasifikasikan oleh Husein 'Ashi sebagai berikut:

1. Qānün as-sababiyyah (hukum sebab-akibat). Yaitu mengaitkan satu peristiwa kepada peristiwa yang lainnya dengan hukum kausalitas. Tidaklah suatu peristiwa terjadi melainkan ada sebab yang melatarinya. Dan tidaklah suatu peristiwa memiliki satu sebab melainkan ia pun akan menjadi sebab bagi peristiwa yang lainnya. Menurut Kuntowijoyo 
(2008), dalam kausalitas, sejarawan harus menganalisis dua hal, yaitu kasus (peristiwa) dan perubahan. Keduanya berbeda dalam akibat (consequence) yang ditimbulkan; kasus bersifat prosedural tanpa perubahan, sedangkan dalam perubahan terjadi perubahan kualitas, yaitu perubahan struktural (structural change) dan perubahan sistem (systemic change).

2. Qānün at-tasyäbuh (hukum analogi). Yaitu mengqiyaskan (menganalogikan) peristiwa masa lalu dengan peristiwa hari ini. Maka fungsi analogi bisa dihasilkan lewat realitas yang serupa dengannya.

3. Qānūn at-thathawmur (hukum evolusi). Yaitu kejadian-kejadian yang mengalami perubahan secara evolusi sesuai dengan perubahan situasi dan kondisi.

4. Qānūn al-muthäbaqah (hukum relevansi). Yaitu hukum yang memastikan seorang ahli sejarah untuk meneliti realitas dan cerita-cerita masa lalu di atas bangunan rasionalitas. Jika realitas dan cerita-cerita itu masuk akal, maka masuk dalam wilayah imkän (besar kemungkinan benarnya. Namun jika tidak masuk diakal, maka masuk dalam wilayah istihālah (besar kemustahilannya) dan bahkan ditolak mentah-mentah.

Dari kritikan dan penawaran metodis yang dihasilkan Ibnu Khaldun, sampai kepada kesimpulan bahwa memahami sejarah tidak terlepas dari dua aspek, yaitu aspek dqaăhir (luaran) dan aspek bäthin (subtantif).

Dari aspek $d z a \bar{h} i r$, sejarah tidak lebih dari sekedar berita-berita masa lalu. Sejarah pada sisi ini hanya mencoba menjawab pertanyaan-pertanyaan elementer yang berkaitan dengan "apa, siapa, kapan" dan "di mana" peristiwa itu terjadi. Pada tahap ini, maka sejarah dapat dikonsumsi oleh masyarakat umum atau masyarakat terpelajar dan masyarakat tidak terpelajar dalam istilah Ibnu Khaldun. Menurut Toto, bahwa memahami sejarah pada sisi luarannya dalam konteks kekinian, disebut dengan sejarah naratif (narratif history). Sejarah naratif hanya berusaha melihat fakta historis sebagai suatu rangkaian data yang dapat berbicara atau dengan istilah lain sebagai $a$ story that told. Menurut Fernand Braudel, sejarah naratif selalu mengklaim untuk menceritakan berbagai peristiwa apa adanya, tanpa interpretasi. Pada prinsipnya, sejarah naratif hanya ingin membuat deskripsi masa lampau dengan merekonstruksikan "apa yang terjadi" sebagai sebuah cerita. Namun menurut Kuntowijoyo, sejarah naratif tidak hanya menuliskan sejarah secara deskriptif dengan sekedar mengemukakan fakta-fakta. Setidaknya ada tiga syarat dalam penulisan sejarah naratif, yaitu colligation, plot, dan struktur sejarah.

Pertama, colligation. Teori ini mengatakan bahwa menulis sejarah itu ialah mencari inner conection (hubungan dalam) antar peristiwa sejarah. Kedua, plot. Plot adalah cara mengorganisasikan fakta-fakta menjadi satu keutuhan. Orang tidak mungkin melakukan penulisan sejarah secara "universal", kecuali dengan cara menyegmentasi kepada beberapa bagian, seperti sejarah politik, sejarah agama, sejarah keluarga, dan sebagainya. Plot dalam sejarah seperti plot dalam sastra, yaitu memerlukan interpretasi dan eksplanasi. Plot juga menghendaki konsekuensi di balik peristiwa, semisal kausalitas tapi berbeda dengannya, sekalipun keduanya adalah sequence. Plot itu sequence yang harus berurutan peristiwanya, sedangkan kausalitas tidak harus berupa peristiwa tetapi bisa hanya berupa kondisi. Ketiga, struktur sejarah. Struktur adalah cara mengorganisasikan. Struktur sejarah diperlukan sebagai rekonstruksi yang akurat.

Sedangkan dari aspek bäthin (subtantif), sejarah tidak hanya sekedar cerita kronik tentang peristiwa masa lalu tapi ia merupakan penalaran kritis (nadzar), penyingkapan kebenaran (tahqiq), timbangan kebenaran bagi semesta alam, dan pengetahuan tentang bagaimana dan mengapa realitas terjadi. Maka dari aspek ini, sejarah menurut Ibnu Khaldun ialah ilmu yang orisinal tentang hikmah dan layak untuk dihitung sebagai bagian dari ilmu-ilmu yang mengandung kebijaksanaan atau filsafat.

Menurut Toto, sejarah pada sisi ini berusaha menjawab dari pertanyaan bagaimana, mengapa, dan apa jadinya. Jawaban terhadap pertanyaan "bagaimana" akan melahirkan suatu 
keterangan historis (historical explanation), dan jawaban terhadap "mengapa" dan "apa jadinya" adalah menyangkut masalah kausalitas yang merupakan puncak studi sejarah. Pemahaman sejarah pada aspek inilah yang kemudian disebut oleh Toto dengan studi sejarah kritis. Husain 'Ashi menyebutnya sebagai at-tafsiri li at-tärikh (interpretation of history).

\section{B. Kompetensi Iman dalam Muqaddimah Ibnu Khaldun}

Ibnu Khaldun dalam kitab al-Muqddimahnya menyebutkan kompetensi yang menjadi capaian dalam mempelajari sejarah tidak hanya bersifat meterialistik (duniawi) saja, tetapi juga bersifat imaterialistik (ukhrawi). Secara lengkap, berikut kutipan langsung dari kitab alMuqaddimah:

Ketahuilah, ilmu sejarah merupakan ilmu yang mulia mazhabnya, besar manfaatnya, dan mulia tujuannya. Ilmu sejarah menyebabkan kita dapat memahami kondisi umat-umat terdahulu, jejak-jejak para nabi, para raja dengan kerajaan dan politik mereka sehingga dapat dijadikan pelajaran oleh orang-orang yang mengambil pelajaran, baik dalam urusan dunia maupun akhirat.

Dari teks di atas, secara eksplisit Ibnu Khaldun menghendaki bahwa tujuan mempelajari ilmu sejarah adalah untuk mengetahui kondisi umat-umat terdahulu, jejak-jejak para nabi, para raja, yang kemudian dapat dipetik pelajarannya untuk kepentingan dunia dan akhirat. Kondisi umat terdahulu yang di sana disebutkan para nabi dan raja, tentu saja mencakup seluruh kondisi kehidupan mereka, baik dari aspek spiritual, sosial, pengetahuan, dan keterampilan. Kondisi-kondisi tersebut ditujukan untuk kepentingan dunia dan akhirat. Dari sini, secara generik kompetensi iman bisa dimasukkan dalam diksi "kepentingan akhirat".

Secara spesifik, tujuan tersebut diimplementasikan oleh Ibnu Khaldun dengan menyebut nama dan ayat-ayat Allah di setiap akhir pembahasan suatu sub bab (pasal) dalam alMuqaddimahnya, sebagai manifestasi dari kompetensi keimanan yang hendak dicapai. Berikut rinciannya dalam bentuk tabel:

Tabel I: Kompetensi Keimanan dalam Kitab Al-Muqadimah

\begin{tabular}{|c|c|}
\hline Judul Pembahasan dalam Kitab al-Muqadd & $\begin{array}{c}\text { Asma Allah/ Ayat yang Dicantumkan di } \\
\text { Akhir Pembahasan }\end{array}$ \\
\hline 1. Pasal Pertama dari Kitab Pertama & $\begin{array}{l}\text { - Dan tidaklah anda diberi } \\
\text { pengetahuan kecuali sedikit (QS. Al- }\end{array}$ \\
\hline $\begin{array}{l}\text { 1.1. Karakter Peradaban Manusia Serta Penopang- } \\
\text { penopangnya Berupa Kehidupan Primitif, } \\
\text { Kehidupan Perkotaan, Kemenangan Suatu } \\
\text { Kelompok, Mata Pencaharian Hidup, Profesi, Ilmu } \\
\text { Pengetahuan dan Sejenisnya Serta Sebab-sebab yang } \\
\text { Melatarinya }\end{array}$ & $\begin{array}{l}\text { Isra: 85) [dicantumkan di } \\
\text { pertengahan ayat dalam membahas } \\
\text { al-'umrān] } \\
\text { - Hanya Allah yang memberikan taufik } \\
\text { dan pertolongan untuk mencapai } \\
\text { kebenaran }\end{array}$ \\
\hline
\end{tabular}

1.2. Pasal ke-1; Peradaban Manusia Secara Umum (Muqaddimah Pertama; Manusia Adalah Makhluk Sosial)

1.3. Muqaddimah Kedua; Bagian Bumi yang Memiliki Peradaban dan Penjelasan atas Sebagian Pohon, Sungai, dan Kawasan

1.4. Catatan Pelengkap untuk Muqaddimah Kedua; Mengapa Belahan Utara Lebih Makmur daripada Belahan Selatan

.5. Muqaddimah Ketiga; Kawasan Pertengahan dan Non-Pertengahan, dan Pengaruh Udara
Hanya Allah yang memberikan taufik dan hidayah

Hanya Allah yang memberikan taufik

Dan di dalam penciptaan langit dan bumi dan perbedaan malam dan siang terdapat tanda-tanda bagi orang-orang yang berpengetahuan. (QS. Al-Baqarah: 164; QS. Ali Imran: 190)

- Kamu sekali-kali tidak akan
menemukan perubahan bagi
sunnatullah itu. (QS. Al-Fath: 23)


Terhadap Warna Kulit Manusia dan Berbagai Macam Kondisinya

2. Pasal Kedua dari Kitab Pertama

2.1. Peradaban Badui, Bangsa-bangsa dan Kabilahkabilah Liar, serta Kondisi-kondisi Kehidupan Mereka, Ditambah Keterangan Dasar dan Kata Pengantar

Pasal Kesatu; Orang-orang Badui dan Orang-orang Kota Merupakan Sama-sama Hasil Alam

\subsection{Pasal Kedua; Orang Arab adalah Kelompok} Alami

2.3. Pasal Ketiga; Orang-orang Badui Lebih Tua daripada Orang-orang Kota dan Mereka adalah Pangkal Peradaban dan Kota-kota

2.4. Pasal Keempat: Orang-orang Badui Lebih Mudah Menjadi Baik daripada Penduduk Kota
Allah yang Maha Pencipta dan Maha Mengetahui.

Allah yang lebih tahu

- $\quad$ Setiap bayi dilahirkan dalam keadaan fitrah (suci). Maka ibu bapaknyalah yang menjadikannya seorang Yahudi, Nasrani, atau Majusi (HR. Al-Bukhari dan Muslim) [diletakan di awal pembahasan]

- Dan Allah Swt. lebih Mengetahui dan Maha Memberi Petunjuk.

2.5. Pasal Kelima; Orang-orang Badui Lebih Berani daripada Orang-orang Kota

3. Pasal Ketiga dari Kitab Pertama

Dan Allah menciptakan apa yang dikehendaki-Nya. (QS. Ali Imran: 47)

Allah Maha Berkuasa atas segala sesuatu.

3.1. Kerajaan-kerajaan Secara Umum, Kerajaan, Kekhalifahan, Jabatan Kepemimpinan, dan Semua yang Berhubungan dengannya

Pasal Kesatu; Kerajaan dan Pemerintahan Secara Umum dapat Berdiri dengan Dukungan Kabilah dan Fanatisme

3.2. Pasal Kedua; Kerajaan yang Telah Stabil dan Kokoh Tidak Membutuhkan Fanatisme

3.3. Pasal Ketiga; Beberapa Putra Mahkota Terkadang Memerintah Tanpa Perlu Fanatisme

3.4. Pasal Keempat; Kerajaan Memiliki Kekuasaan Kuat Berlandaskan Agama, Baik Melalui Kenabian Maupun Seruan Kebenaran

3.5. Pasal Kelima; Dakwa Keagamaan akan Memperkuat Fanatisme pada Kerajaan Sekaligus Bagian Darinya

\section{Pasal Keempat dari Kitab Pertama}

4.1. Negeri-negeri, Kota-kota dan Pembangunan Lainnya serta Peristiwa yang Berkaitan dengannya

Pasal Kesatu; Kerajaan Muncul Lebih Dahulu daripada Madinah (Kota) dan Mishr (lbukota)
(QS. Al-Baqarah: 29).

Dialah Allah yang mencukupi kami dan sebaik-baiknya pelindung

Allah Swt. berkehendak melimpahkan kekuasaan-Nya kepada siapa saja yang dikehendaki-Nya. (QS. Al-Baqarah: 247)

Dan Allah menetapkan hukum (menurut kehendak-Nya), tidak ada yang dapat menolak ketetapannya. (QS. Ar-Ra'd: 41)

Walaupun engkau membelanjakan semua (kekayaan) yang berada di bumi, niscaya engkau tidak dapat mempersatukan hati mereka, akan tetapi Allah telah mempersatukan hati mereka. Sesungguhnya di Maha gagah lagi Maha Bijaksana. (QS. Al-Anfal: 63)

Allah Maha Menguasai atas segala sesuatu.

Dan Allah yang lebih tahu dan Maha

Pemberi Petunjuk 
4.2. Pasal Kedua; Kekuasaan Mengharuskan Warganya untuk Mendiami Amshar (lbukota)

4.3. Pasal Ketiga; Kota-kota Besar dan Bangunanbangunan Tinggi Hanya Bisa Dibangun oleh Banyak Kekuasaan

4.4. Pasal Keempat; Bangunan yang Sangat Besar Tidak Dapat Didirikan Sendirian oleh Suatu Kerajaan

4.5. Pasal Kelima; Yang Harus Diperhatikan dalam Membangun Kota dan Akibatnya Jika Hal Itu Diabaikan

5. Pasal Kelima dari Kitab Pertama
5.1. Mata Pencaharian dan Kewajibannya, Baik Berupa Usaha Maupun Kerajinan-Keterampilan dan Berbagai Kondisi yang Menimpa

Pasal Kesatu; Hakikat dan Penjelasan Tentang Rezeki dan Hasil Usaha; Bahwa Hasil Usaha adalah Nilai dari Pekerjaan Manusia

5.2. Pasal Kedua; Bidang-bidang Mata Pencaharian dan Cara-caranya

5.3. Pasal Ketiga; Jasa Pelayanan Bukanlah Termasuk Mata Pencaharian yang Alami 5.4. Pasal Keempat; Mencari Harta Terpendam dan Harta Karun adalah Mata Pencaharian yang Tidak Wajar

5.5. Pasal Kelima; Jabatan Merupakan Sarana Efektif untuk Meraih Kekayaan

6. Pasal Keenam dari Kitab Pertama

6.1. Berbagai Jenis IImu Pengetahuan, Metode Pengajaran, Cara Memperoleh dan Berbagai Dimensinya, dan Segala Sesuatu yang Berhubungan dengannya

Pasal Kesatu; Manusia Makhluk Berpikir

6.2. Pasal Kedua; Semesta Alam Hanya Bisa Aktif dengan Akal Manusia

\subsection{Pasal Ketiga; Nalar Eksperimen dan Cara} Kerjanya

6.4. Pasal Keempat; IImu-ilmu Manusia dan Ilmuilmu Malaikat

6.5. Pasal Kelima; Ilmu-ilmu Para Nabi
Dan Allah yang lebih tahu dan Maha Pemberi Petunjuk. Tidak ada tuhan kecuali diri-Nya

Allah Menciptakan apa yang Dia

kehendaki. (QS. Ali Imran: 47)

dan mengukuhkan apa yang Dia inginkan. (QS. Al-Maidah: 1)

Allah menciptakan kalian dan apa yang kalian lakukan. (QS. Ash-Shafat: 96)

Dan Allah yang lebih tahu

Allah yang menentukan siang dan malam.

(QS. Al-Muzammil: 20)

Allah Swt. Maha Kuasa atas segala sesuatu.

Allah memberi rezeki orang yang dikehendakinya dengan tanpa perhitungan. (QS. Al-Baqarah: 212)

Allah Swt. berhak melimpahkan rezeki kepada siapa saja yang dikehendaki-Nya dengan tanpa perhitungan. (QS. AlBaqarah: 212)
Karena itu, pahamilah dengan baik. Allah Swt. selalu menambah anugerah-Nya kepada makhluk-Nya sesuai dengan yang dikehendaki-Nya.

Allah Swt. telah menjadikan pendengaran, penglihatan, hati bagi kalian. Sedikit sekali kalian bersyukur. (QS. Al-Mukminun: 78)

Dialah yang mengajarkan manusia apaapa yang tidak diketahuinya. (QS. AlAlaq: 5)

Dan di atas tiap orang-orang yang berpengetahuan itu ada Yang Maha Mengetahui.

Dari sampel yang diambil oleh peneliti menunjukkan bahwa seobjektif dan serasional kitab al-Muqaddimah, unsur-unsur keimanan tetap dimasukkan di dalamnya. Ayat al-Qur'an dan asmä Allah yang dicantumkan oleh Ibnu Khaldun di setiap akhir pembahasan pasalnya, menunjukkan bahwa adanya integralistik antara ilmu sejarah yang masuk dalam kategori ilmu 
humaniora dengan unsur-unsur keimanan sebagai kategori ilmu agama. Keduanya beriringan secara harmoni.

Namun demikian, dengan dicantumkannya ayat-ayat al-Qur'an yang relevan di setiap akhir pembahasan pasal, karyanya ini justru dituding sebagai karya yang tidak ilmiah. Unsurunsur agama yang dimasukkan dalam karyanya ini menyebabkan pihak lain berani menjustifikasi kitab al-Muqaddimah sebagai karya yang tidak ilmiah.

Alasan di atas di bantah oleh al-Khudhairi. Ia menyatakan bahwa pencantuman nama Allah atau ayat al-Qur'an saat mengakhiri pembahasan setiap pasalnya, tidak berarti bahwa Ibnu Khaldun sedang menghindar dari dalil-dalil rasional. Justru ia lakukan setelah mengemukakan dalil-dalil rasional. Kedua, mengakhiri pembahasan dengan menyebutkan nama Allah merupakan kultur pada masa itu bahkan jauh sebelum masa Ibnu Khaldun. Ketiga, hendaklah tidak dipisahkan Ibnu Khaldun dengan akar-akar pemikiran Islamnya.

Oleh sebab itu, menurut Muhammad Iqbal, bahwa seluruh semangat al-Muqaddimah, yang merupakan manifestasi pemikiran Ibnu Khaldun, di ilhami dari al-Qur'an sebagai sumber utama dan pertama ajaran Islam (Iqbal, 1966).

Bahkan menurut Hasan Sa'ati, terdapat istilah-istilah dan teori-teori yang dikemukakan oleh Ibnu Khaldun dalam kitab al-Muqaddimahnya terilhami dengan istilah yang dipergunakan di dalam al-Qur'an. Kata 'umrän banyak digunakan di dalam kitab al-Muqaddimah, ternyata terilhami dari ayat yang berbunyi:

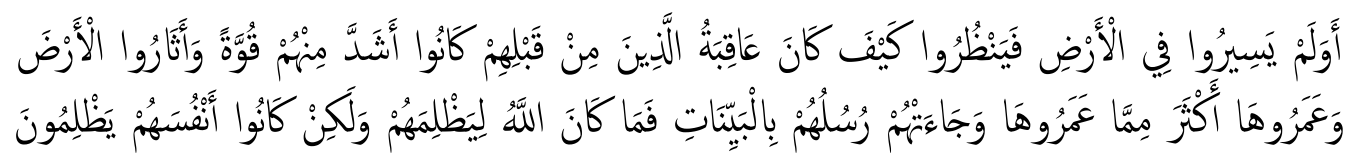

Dan Apakah mereka tidak mengadakan perjalanan di muka bumi dan memperhatikan bagaimana akibat (yang diderita) oleh orang-orang sebelum mereka? orang-orang itu adalah lebih kuat dari mereka (sendiri) dan telah mengolah bumi (tanah) serta memakmurkannya lebih banyak dari apa yang telah mereka makmurkan. Dan telah datang kepada mereka rasul-rasul mereka dengan membawa bukti-bukti yang nyata. Maka Allah sekali-kali tidak berlaku dzalim kepada mereka, akan tetapi merekalah yang berlaku dzalim kepada diri sendiri. (QS. Ar-Rum: 9)

Termasuk teori gerak sejarah. Ibnu Khaldun menyebutkan bahwa usia suatu generasi umurnya adalah empat puluh (40) tahun. Dan usia suatu pemerintahan biasanya tidak melebihi dari tiga generasi atau seusia seratus dua puluh (120) tahun. Teori ini diilhami dari ayat al-Qur'an yang berbunyi sebagai berikut:

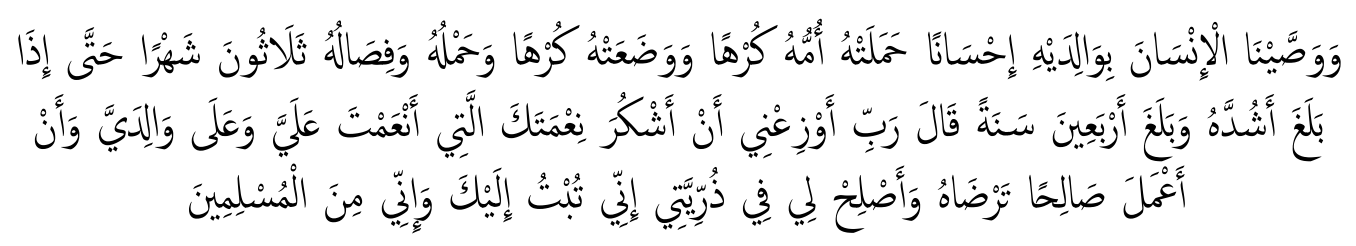

Kami perintahkan kepada manusia supaya berbuat baik kepada ibu bapaknya, ibunya mengandungnya dengan susah payah, dan melahirkannya dengan susah payah (pula). Mengandungnya sampai menyapihnya adalah tiga puluh bulan, sehingga apabila dia telah dewasa dan umurnya sampai empat puluh tahun ia berdoa, "Ya Tuhanku, tunjukilah aku untuk mensyukuri nikmat Engkau yang telah Engkau berikan kepadaku dan kepada ibu bapakku dan supaya aku dapat berbuat amal yang saleh yang Engkau Ridhoi; berilah kebaikan kepadaku dengan (memberi kebaikan) kepada anak cucuku. Sesungguhnya aku bertobat kepada Engkau dan sesungguhnya aku termasuk orang-orang yang berserah diri”. (QS. Al-Ahqaf: I5)

Oleh karena itu, pemikiran-pemikiran Ibnu Khaldun yang terkandung dalam karyanya alMuqaddimah, sarat dengan sentuhan al-Qur'an. Maka dari itu, Hasan Sa'ati yang menyoroti 
pemikiran Ibnu Khaldun dari aspek sosiologinya menyebutkan bahwa Ibnu Khaldun telah menciptakan ilmu sosiologi qur'ani ('ilmu al-'̌jtima’iy al-qur'āni) (Sa’ati, 2006).

Senada dengan pandangan di atas, Imadudin Khalil mengungkapkan bahwa argumentasiargumentasi Ibnu Khaldun dalam mengkaji realitas sejarah dibangun atas dasar agama. Teorinya tentang 'ashabiyyah (fanatisme/ loyalitas/ solidaritas) sebagai penopang kekuasaan merupakan interpretasi Ibnu Khaldun terhadap kekuatan hati; karena loyalitas, fanatisme, dan solidaritas bersumber dari hati. Akan tetapi, hati sebagai sumber kekuatan dari 'ashabiyyah akan membangun kesatuan dan ikatan kuat manakala jika dibangun atas dasar agama. Argumennya itu didasarkan pada ayat al-Qur'an berikut ini:

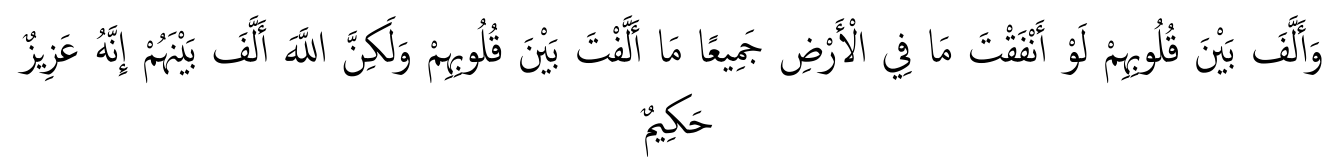

Dan Dia (Allah) yang mempersatukan hati mereka (orang-orang yang beriman). Walaupun kamu membelanjakan semua (kekayaan) yang berada di bumi, niscaya kamu tidak dapat mempersatukan hati mereka, akan tetapi Allah telah mempersatukan hati mereka. Sesungguhnya Dia Maha gagah lagi Maha Bijaksana. (QS. Al-Anfal: 63)

Ayat ini kemudian ditafsirkan oleh Ibnu Khaldun untuk menguatkan argumentasinya tentang teori 'ashabiyyahnya. Berikut interpretasi Ibnu Khaldun mengenai ayat tersebut:

Pada dasarnya, jika hati terintervensi oleh nafsu yang jelek dan pragmatisme duniawi, maka akan tumbuh pertikaian dan perpecahan. Akan tetapi jika hati condong pada kebenaran, maka pragmatisme dunia dan nafsu yang jelek akan sirna; hati akan menuju Allah dan akan selalu dalam persatuan, maka pertikaian pun akan hilang, perselisihan akan mereda, solidaritas akan muncul, saling tolong menolong akan tumbuh, dan akan se-iya se-kata dalam semua aspek. Maka dari itu, negara akan menjadi kuat dan besar.

Menurut Imadudin Khalil bahwa perkataan Ibnu Khaldun di atas, sampai pada kesimpulan bahwa suatu negara tidak akan tegak dan menjadi besar kecuali dibangun atas dasar keimanan. Di sini Ibnu Khaldun berulang kali menegaskan bahwa teori 'ashabiyyah yang ia bangun merupakan 'ashabiyyah dalam paradigma al-Qur'an; bukan 'ashabiyyah sebagai gejala psikologi-positivistik (Khalil, 1983).

Dengan demikian, Ibnu Khaldun mengintegrasikan antara temuan-temuannya yang bersifat rasionalis-empiris dengan wahyu; keduanya tidak didikotomikan sebagaimana watak peradaban barat hari ini. Padahal, corak saintis Barat dengan Timur sangat jauh berbeda. Cemil Akdogan menjelaskan, bahwa sains Islam adalah produk pendekatan tauhidik, sedangkan sains Barat modern adalah produk dari pendekatan dualistik. Dalam Islam, sains tidak terpisahkan dari Islam. Sedangkan di Barat, sains bersifat "bebas Tuhan" (godless).

\section{Kesimpulan}

kompetensi iman dalam pemikiran sejarah Ibnu Khaldun bila dilihat dari analisisnya menggunakan pendekatan (approach) dzähiriyyah dan bäthiniyyah. Pendekatan dzaähiriyyah sejarah dipahami sebagai sejarah naratif yang hanya membahas pertanyaan elementer (apa, siapa, kapan, dan di mana) saja. Sedangkan pendekatan bäthiniyyah sejarah dipahami sebagai sejarah kritis yang tidak hanya sekedar berupa cerita kronik tentang peristiwa masa lalu saja, tapi juga merupakan penalaran kritis (nadzar), penyingkapan kebenaran (tahqiq), timbangan kebenaran bagi semesta alam, dan pengetahuan tentang bagaimana dan mengapa realitas terjadi. Dengan kedua pendekatan itulah kemudian pemikiran sejarah Ibnu Khaldun yang tertuang dalam karya magnum opusnya, al-Muqaddimah, dipandang sebagai karya ilmiah yang bersifat empiris-rasionalis. Meski demikian, Ibnu Khaldun mengungkapkan bahwa di antara tujuan mempelajari ilmu sejarah ialah memetik pelajaran untuk kepentingan dunia dan 
akhirat. Maka di sinilah letak kompetensi iman sebagai output dari mempelajari ilmu sejarah, maka tak heran di setiap akhir pembahasan perpasalnya Ibnu Khaldun mencantumkan ayatayat yang relevan dengan tema yang dikajinya.

\section{Daftar Pustaka}

'Ashi, H. (1991). Ibnu Khaldinn Mu'arrikhan, Beirut: Darul Kitab Ilmiyyah. 'Itr, N (1997). Manhaj an-Naqd fi 'Ulüm al-Hadits, Damaskus: Darul Fikr. Al-Badawi, A. (1962). Mu'allafät Ibnu Khaldūn, Mesir: Darul Ma’arif.

Al-Hushri, S. (1967). Dirāsāt 'an Ibni Khaldūn, Beirut: Darul Kitab al-'Arabi. al-Khuadhari, Z. (1979). Falsafah at-Tärkh 'ind Ibni Khalūn, Kairo: Darul Tsaqafah. ath-Thabari, I.J. (2001). Jämi'u al-Bayān 'an Ta'willi Äyi al-Qur'ān, Kairo: Daru Hijr.

Sujati, B (2018.), Konsepsi Pemikiran Filsafat Sejarah dan Sejarah Menurut Ibnu Khaldun, TAMADDUN; Jurnal Sejarah dan Kebudayaan Islam, 6(2)

Husaini, A(2009). Hutang Barat Pada Islam, Jurnal Islamia, Vol. V No. 1

Iqbal, M. (1966). Membangun Kembali Pikiran Agama dalam Islam terj. Ali Audah, Jakarta: Tintamas.

Kaelan. (2010). Metode Penelitian Agama Kualitatif Interdisipliner, Yogyakarta: Paradigman.

Khaldun, I. (2004). Muqaddimah Ibnu Khaldūn, Damaskus: Dar Ya'rib.

Khalil, I. (1983). Ibnu Khaldun Islämiyya, Beirut: Maktab al-Islami.

Kuntowijoyo. (2008). Penjelasan Sejarah, Yogyakarta: Tiara Wacana.

Kurniawan, A. (2018). Metodologi Penelitian Pendidikan, Rosdakarya: Bandung.

Renier, G.J. (1997). Metode dan Manfaat Ilmu Sejarah, terj. A. Muin Umar, Yogyakarta: Pustaka Pelajar.

Sa'ati, H. (2006). Ibnu Khaldun Mubdi'an; Qiräah Jadìdah li Fikribi wa Manbajibi fi 'ilmi ijtimā, Kairo: Majlis A'la li Tsaqafah.

Saepudin, D., \& Saifudin, S. (2019). VISI PENDIDIKAN ISLAM: PERSPEKTIF IBN KHALDUN. Tawazun: Jurnal Pendidikan Islam, 12(2), 151-171. doi: 10.32832/tawazun.v12i2.2688

Samsinas, (2009) Ibn Khaldun: Kajian Tokoh Sejarah dan Ilmu-ilmu Sosial, HUNAFA; Jurnal Studia Islamika, 6(3)

Sanjaya, W. (2013). Penelitian Pendidikan; Jenis, Metode dan Prosedur, Jakarta: Interpratama.

Suharto, T. (2003). Epistemologi Sejarah Kritis Ibnu Khaldun, Yogyakarta: Fajar Pustaka.

Syamsul H. dan Wakhidah, A.N. (2015) Konsep Pendidikan Islam Ibn Khaldun dan Relevansinya Terbadap Pendidikan Nasional, PROFETIKA; Jurnal Studi Islam, 16(1). 